\title{
NOVEL CORONAVIRUS DISEASE (COVID-19): AN UPDATE
}

\author{
Nayak $N^{1}$ and Rai $S K^{2}$
}

${ }^{1}$ Department of Microbiology, Manipal College of Medical Sciences, Pokhara and ${ }^{2}$ Department of Microbiology, Nepal Medical College, Kathmandu, Nepal

\begin{abstract}
At present, a novel Corona Virus called Severe Acute Respiratory Syndrome corona virus (SARSCov-2) has caused pandemic infection. This virus has been thought to be of zoonotic origin specially originating from bats. This Virus originated from wet market in Wuhan, China in December 2019. A small cluster of Pneumonia cases that occured in Wuhan in December 2019 was named COVID-19 (Corona Virus Disease) by World Health Organization (WHO). The Covid-19 is still on the rise across the globe. As there is no treatment available for the SARS-Cov-2, it is important to mantain social distance, practice frequent hand-washing and use mask.
\end{abstract}

\section{KEYWORDS}

COVID-19, novel Corona virus, pandemic

\section{CORRESPONDING AUTHOR}

Dr. Niranjan Nayak

Professor,

Department of Microbiology, Manipal College of

Medical Sciences, Pokhara, Nepal 33700

Email: niruni2000@yahoo.com

Orcid ID: 0000-0001-6813-3596

DOI: https://doi.org/10.3126/nmcj.v22i1-2.30049 


\section{COVID-19: More than just the common cold}

It is well known that some 100 odd serotypes of Rhinoviruses ("rhino" meaning "nose", the organ primarily affected with the symptom of running nose), typed by neutralization test, cause common cold, which is the most common infectious disease of man. Human Coronaviruses (HCoVs) have long been considered as the second most familiar agents responsible for this condition in otherwise healthy people. However, what $21^{\text {st }}$ century witnessed was more than just the "common cold". Two highly pathogenic HCoVs; severe acute respiratory syndrome coronavirus (SARS-CoV) and Middle East respiratory syndrome coronavirus (MERS-CoV) emerged in 2003 in the Guangdong Province of China and in the year 2012 in Saudi Arabia, respectively. ${ }^{1,2}$ These two Coronaviruses caused global epidemics with high morbidity and mortality. Both these viruses probably originated from their zoonotic reservoirs. ${ }^{1,2}$

Very recently, in December 2019, there was an outbreak of pneumonia of unknown etiology in similarity with SARS-CoV, and secondly, like SARS-CoV, it has affinity for the angiotensin converting enzyme 2 (ACE -2) receptor found in the respiratory tract of man.

However, the division of "International Classification of Diseases" under the World Health Organization (WHO) during the same period proposed a new name for the disease as "COVID-19" (CO=Corona, VI=virus, $\mathrm{D}=$ disease, 19 for 2019) 6 and the agent causing "COVID-19" as "COVID-19 virus", rather than "SARS-CoV-2", earlier proposed by ICTV, in order to avoid reference to any specific geographical area or stigmatization on any place or group of people. ${ }^{7}$

\section{Coronavirus: Morphology}

Coronaviruses are large pleomorphic spherical particles (approximately $120 \mathrm{~nm}$ ) with bulbous surface projections (Fig. 1). These are positive sense RNA viruses and the viral envelope consists of a lipid bilayer where the membrane (M), envelope (E) and spike (S) structural proteins are

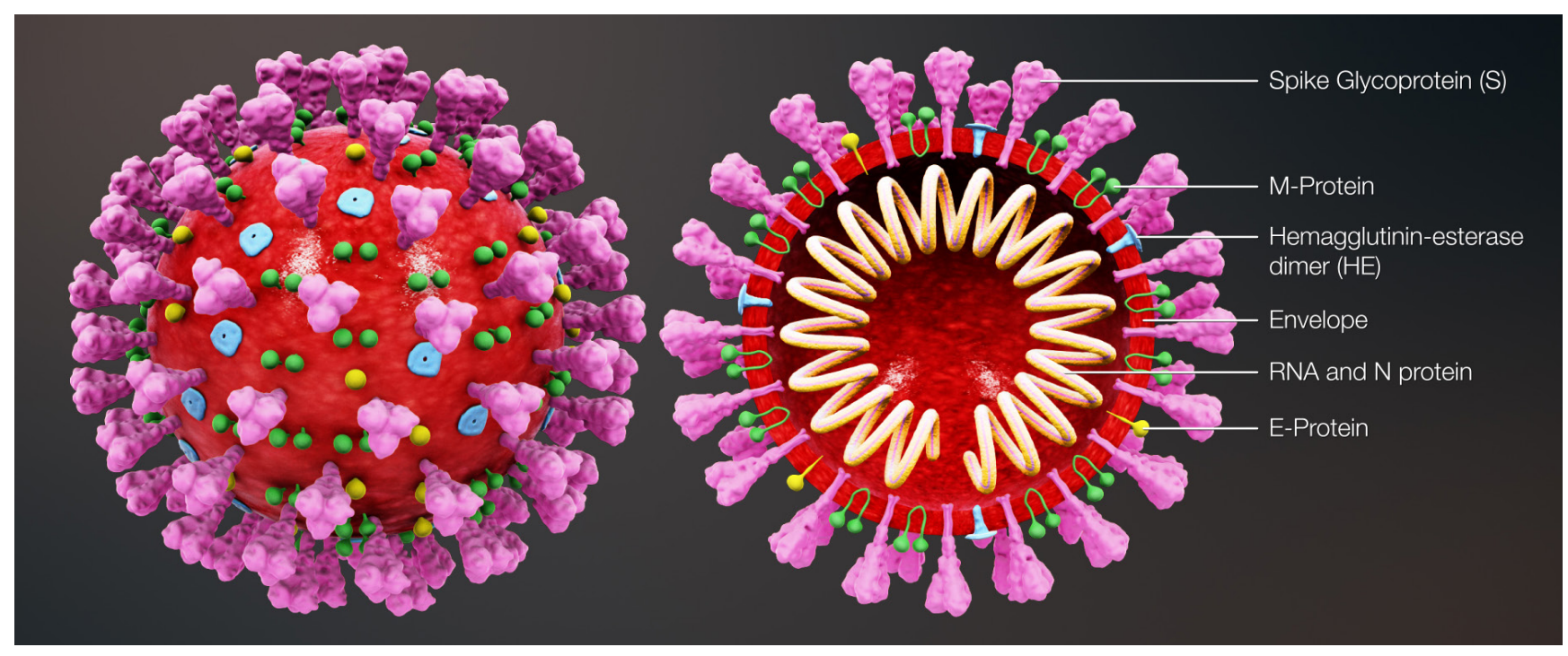

Fig. 1: Coronavirus

Wuhan, China, which raised alarm not only within China but internationally. ${ }^{3}$ In January 2020, a Novel Coronavirus was isolated from the lower respiratory specimens of these patients and was identified as an enveloped RNA virus, belonging to family, Betacoronavirus. ${ }^{4}$ This novel virus was then named "2019-nCoV". Thereafter, Sanghai Public Health Clinical Centre and School of Public Health established the whole genomic sequence of the virus and the sequence pattern revealed that "2019-nCoV" had some amino acid homology to SARS-CoV of 2003..$^{5}$ Thus, on $11^{\text {th }}$ February 2020, the virus was renamed by the International Committee on Taxonomy of Viruses (ICTV) as "severe acute respiratory syndrome coronavirus 2 (SARS-CoV-2)", firstly becauseof its phylogenetic anchored ${ }^{8,9}$ A subset of Coronaviruses (specifically the members of Betacoronavirus subgroup A) also have a shorter spike-like surface protein called hemagglutinin esterase (HE). ${ }^{10}$

\section{Emergence of COVID-19 virus: Does history repeat itself?}

The virus is thought to have an animal origin. ${ }^{11.12}$ There had been a continuous common source of the outbreak in December 2019, which would imply that several animals to human zoonotic events would have occurred at the Wuhan Seafood Wholesale Market, China. Among the cluster of pneumonia cases that occurred in December 2019 in Wuhan, majority had the history of exposure to the same seafood market selling many live 
animals. ${ }^{12}$ Following this there could have been transmission from human to human via droplets and fomites, as hypothecated in January $2020 .^{12,13}$

The origin of the virus is still conjectural. However, evidences in the past had shown that whole genome sequences of corona like viruses obtained from bats matched with those of SARSCoV and MERS-CoV. Thus, it was proposed that bats could be the natural reservoirs of these two viruses. Since, SARS-CoV, MERS-CoV and the new COVID-19 virus all belong to the family of Betacoronavirus, ${ }^{11}$ it is, therefore, believed that COVID-19 virus also might have originated from bats, and later on could have disseminated to other intermediary animals before making a leap to humans. Such zoonotic spill overs were documented recently for SARS-CoV and for MERS-CoV. ${ }^{14,15}$ The 2002-2003 SARS-CoV outbreak, for example, was traced back to palm civets and other small mammals, while MERS sprang from camels to man. The origin for this zoonotic event could be bats, acting as natural hosts, as shown for many other viruses, such as Nipah virus, Hendra virus, Ebola virus, and Lyssa virus. ${ }^{15}$

So far as COVID-19 virus is concerned, intermediary hosts are still under scrutiny, deserving more detailed field studies assessing infection and seroprevalence. ${ }^{16}$ Nevertheless, as supported by current data and evidences, human infection in the whole sale wet market in Wuhan, China could have occurred because of intimate exposure to wild animals. Eventually human to human transmission could happen via droplets and fomites, albeit to a lesser extent via consumption of undercooked animal and sea food.

\section{Pathogenesis of COVID-19}

The exact pathogenesis of COVID 19 is not completely understood. Whatever limited information is available, it has been derived from conclusions obtained from the studies conducted on SARS-CoV and MERS-CoV. It was shown that increased amounts of pro-inflammatory cytokines, like IL1 $\beta$, IL6, IL12, MCP1, IFN $\gamma$ in serum were associated with pulmonary inflammation and extensive lung damage in SARS patients. ${ }^{17}$ MERS-CoV infection was also reported to induce increased concentrations of proinflammatory cytokines, such as, IL1, IL15, TNFa and IFN ${ }^{18}$ Others noted recently that patients infected with COVID 19 had high amounts of IL1 $\beta$, IFN $\gamma$, MCP1 leading to activation of TH1 response. ${ }^{2}$ Those patients with complicated COVID 19 disease with very high amounts of circulating pro-inflammatory cytokines needed urgent ICU admission. In a majority of these patients, local lung inflammation spilled over into systemic circulation, giving rise to sepsis necessitating immediate hospitalization, exemplifying the condition akin to cytokine storm. Such high elevation of pro-inflammatory cytokines was not found in patients who did not require ICU admission, suggesting that cytokine storm was associated with disease severity. ${ }^{19}$

\section{Clinical Characteristics of COVID-19}

According to the WHO estimation, the incubation period ranges from 1-14 days with a median incubation period of five to six days. ${ }^{7}$ Those infected may either be asymptomatic or develop symptoms. The commonest clinical manifestations include fever, dry cough, and fatigue. ${ }^{20}$ There may be other features like shortness of breath, myalgia, and headache. Diarrhea and upper respiratory symptoms such as sneezing, runny nose, sore throat are less frequently observed., $5,7,20$ Prognosis was poor in those with underlying conditions like diabetes, hypertension, or cardiovascular diseases. Median time from the onset of symptoms to death was found to be 14 days, and death rate in men was estimated to be $2.8 \%$ and in females $1.7 \% \%^{5,7,20}$ meaning males are more vulnurable to death. Major complications included acute respiratory distress syndrome, pneumonias, acute cardiac injury, acute kidney injury, and secondary bacterial infections. ${ }^{17,20}$

\section{Laboratory Diagnosis}

Patient under investigation (PUI): In order to categorize an individual as PUI, the clinician should ask the individual the following questions:

1. Does the person have fever or symptoms of lower respiratory infection, such as cough or shortness of breath?

2. Has the individual travelled within 14 days of the onset of symptoms?

3. Has the individual had close contact with a person confirmed with COVID-19?

Specimens to be collected: Once the person has been identified as PUI, he/she should be provided with a mask, and taken to an examination room, which should be located away from the crowded areas of the hospital (minimum 6 feet apart). The doctor examining the patient should wear personal protection equipment (PPE) to prevent direct contact to body and eye and to prevent air borne transmission. Specimen collected from the upper respiratory tract includes (1) Nasopharyngeal swab and (2) Oropharyngeal swab.

Synthetic fiber swabs with plastic shafts are preferred over calcium alginate swabs or cotton tipped swabs with wooden shafts, as cotton and calcium alginate may inactivate the virus and may interfere with the PCR test result. The swabs 
should immediately be placed in sterile tubes containing 2-3 ml of viral transport media (VTM).

For collecting in ideal nasopharyngeal swab, a sterile swab should be inserted into the nostril parallel to the palate until the swab touches the nasopharyngeal area. Instead of removing immediately, the swab should be placed in contact with the area for a few seconds to absorb secretions. Oropharyngeal swabs are collected by swabbing the posterior pharyngeal wall and both tonsillar fossae, avoiding touching the tongue and other oral mucosal parts.

The above two specimens are the most frequently collected ones which are recommended for the molecular identification of the pathogen. However, it is advisable to maintain the cold chain for the transport of the specimens in VTM before processing. Tables 1 and 2 below give the details of collection storage and transport of all possible samples for the diagnosis of COVID-19. ${ }^{21}$
Tests performed in expert laboratories for patients meeting the case definition.

Nucleic acid amplification technique i.e. RT PCR (reverse transcriptase Polymerase Chain Reaction) assay or real time RT PCR assay is performed from following specimens collected and transported in an ideal manner.

Upper respiratorysamples such as nasopharyngeal aspirate, oropharyngeal aspirate, nasopharyngeal wash, nasal wash and lower respiratory specimen such as sputum and bronchoalveolar lavage can be collected. To confirm clearance of virus, sample collection should be repeated until the results are negative on two consecutive samples.

Whole genome sequencing from the afore mentioned samples is performed only by reference laboratories in order to ascertain if the genomic configuration of present local isolate matches with that of COVID-19 virus.

Table 1: Guidelines on specimen collection-1 (WHO2018 protocol to investigate nonseasonal influenza and other emerging acute respiratory diseases)

\begin{tabular}{|c|c|c|c|c|}
\hline Specimen type & $\begin{array}{l}\text { Collection } \\
\text { materials }\end{array}$ & Transport & $\begin{array}{l}\text { Storage till } \\
\text { testing }\end{array}$ & Comment \\
\hline $\begin{array}{l}\text { Nasopharyngeal and } \\
\text { oropharyngeal swab }\end{array}$ & $\begin{array}{l}\text { Dacron or } \\
\text { polyster }\end{array}$ & $4^{\circ} \mathrm{C}(\mathrm{VTM})$ & Within 5 days & $\begin{array}{l}\text { Both may be placed } \\
\text { in the same tube to } \\
\text { increase better yield }\end{array}$ \\
\hline Bronchoalveolar lavage & $\begin{array}{l}\text { Sterile } \\
\text { container }\end{array}$ & $4^{\circ} \mathrm{C}(\mathrm{VTM})$ & $\begin{array}{l}\text { Within } 48 \\
\text { hours }\end{array}$ & $\begin{array}{l}\text { May be some dilution } \\
\text { of pathogen: still } \\
\text { worthwhile sample }\end{array}$ \\
\hline $\begin{array}{l}\text { Tracheal aspirate, NP } \\
\text { aspirate, Nasal wash }\end{array}$ & $\begin{array}{l}\text { Sterile } \\
\text { container }\end{array}$ & $4^{0} \mathrm{C}(\mathrm{VTM})$ & $\begin{array}{l}\text { Within } 48 \\
\text { hours }\end{array}$ & - \\
\hline
\end{tabular}

Table-2: Guidelines on specimen collection-2 (WHO2018 protocol to investigate nonseasonal influenza and other emerging acute respiratory diseases)

\begin{tabular}{|c|c|c|c|c|}
\hline Specimen type & $\begin{array}{l}\text { Collection } \\
\text { materials }\end{array}$ & Transport & $\begin{array}{l}\text { Storage till } \\
\text { testing }\end{array}$ & Comment \\
\hline Sputum & $\begin{array}{l}\text { Sterile } \\
\text { container }\end{array}$ & $4^{\circ} \mathrm{C}$ & $\begin{array}{l}\text { Within } 48 \\
\text { hours }\end{array}$ & $\begin{array}{l}\text { Ensure the material is from } \\
\text { lower respiratory tract }\end{array}$ \\
\hline $\begin{array}{l}\text { Biopsy / Autopsy } \\
\text { tissue }\end{array}$ & $\begin{array}{l}\text { Sterile } \\
\text { container }\end{array}$ & $4^{\circ} \mathrm{C}$ & $\begin{array}{l}\text { Within } 24 \\
\text { hours }\end{array}$ & - \\
\hline Serum 2 samples & $\begin{array}{l}\text { Serum } \\
\text { separator tube }\end{array}$ & $4^{\circ} \mathrm{C}$ & $\begin{array}{l}\text { Within } 5 \\
\text { days }\end{array}$ & $\begin{array}{c}\text { Acute } 1^{\text {st }} \text { week and } \\
\text { Convalescent } 2-3 \text { weeks }\end{array}$ \\
\hline Whole blood & Collection tube & $4^{\circ} \mathrm{C}$ & $\begin{array}{l}\text { Within } 5 \\
\text { days }\end{array}$ & Antigen detection $1^{\text {st }}$ week \\
\hline Urine & $\begin{array}{l}\text { Multipurpose } \\
\text { container }\end{array}$ & $4^{0} \mathrm{C}$ & $\begin{array}{l}\text { Within } 5 \\
\text { days }\end{array}$ & - \\
\hline
\end{tabular}




\section{Treatment of COVID 19}

There are recent reports that remdesivir and chloroquine phosphate efficiently inhibited SARS-CoV-2 in vitro. ${ }^{22}$ Remdesivir is a nucleoside analogue. This drug was tried in the first patient infected with COVID-19 virus in the United States and there was marked improvement in the clinical condition of the patient. A phase III clinical trial against COVID-19 virus was launched in Wuhan on February 4, 2020. But, as an experimental drug, remdesivir is not expected to be commonly available to treat a large number of patients.

However, hydroxychloroquine sulfate, a derivative of chloroqine appears to be another promising drug for large scale use due to its proven safety record and a relatively low cost. Moreover, it is widely available, as it is often used to treat autoimmune diseases such as systemic lupus erythematosus and rheumatoid arthritis, and is less toxic than chloroquine.

\section{How chloroquine acts against coronavirus?}

Both chloroquine and hydroxychloroquine are weak bases which elevate the $\mathrm{pH}$ of acidic intracellular organelles, such as endosome/ lysosome, essential for membrane fusion. ${ }^{23}$ Since acidic $\mathrm{pH}$ is required for the virus host target cell fusion, an increase in the $\mathrm{pH}$ of lysosomal/endosomal compartment, obviously disrupts the normal viral function. Secondly chloroquine/hydroxychloroquine interfere with the glycosylation of the cellular receptor ACE2 in the respiratory epithelial cells. Terminal glycosylation inhibition of ACE-2 results in conformational changes of ACE-2 molecules, disrupting the host receptor virus interaction, thereby restricting the virus entry inside the host target cell. Thirdly, chloroquine acts as an ionophoric agent for zinc ions and thus increases the flux of zinc ions into the cytoplasm of host cells. Zinc ions inactivate RNA dependent RNA polymerase which, eventually, prevents COVID 19 polymerisation intracellularly. Prophylactic dose of chloroquine has been recommended to be 500 mg once weekly for adults and $8.3 \mathrm{mg} / \mathrm{kg}$ once weekly for children for three weeks.

In conclusion, the WHO has declared COVID-19 infection a public health emergency of international concern. Till the end of June 2020, over ten million people have been infected out of them, over five hundred thousand have died of COVID-19 globally. Given the rapid spread of the disease globally, the understanding of disease pathogenesis, accurate diagnosis of cases and their management is of primary importance. Recent clinical investigations found that high concentrations of cytokines were detected in plasma of critically ill patients infected with COVID-19 virus, which could suggest that cytokine storm was associated with disease severity. One should follow the WHO guidelines for proper collection of samples from suspected cases in order to arrive at a rapid and accurate diagnosis. Hydroxychloroquine, other than its antiviral activity, is safe and is an effective antiinflammatory agent that has extensively been used in autoimmune diseases, and therefore, can significantly decrease the production of cytokines, particularly so of pro-inflammatory factors. Considering the high contagious nature of this pathogen, each country, nation and individual should adhere to the interim guidelines laid down by the WHO on the containment of the virus i.e. social distancing, frequent hand washing and use of masks while going out.

\section{REFERENCES}

1. de Wit E, van Doremalen N, Falzarano D, Munster VJ. SARS and MERS : recent insights into emerging coronaviruses. Nat Rev Microbiol 2016; 8: 523-34.

2. Song Z, XU Y, Bao L et al. From SARS to MERS: thrusting coronaviruses into the spotlight. Viruses 2019; 11. ii: E59. doi:10.3990/v11010059.

3. WHO. Novel coronavirus-China. Jan 12.2020.http/ www.who.int/csr/don/12-january-2020-novelcoronovorus-china/en (accessed Jan19.2020).

4. Zhu N, Zhang D, Wang W et al. A novel Coronavirus from patients with pneumonia in China, 2019. New Engl J Med 2020;a 382: 727-33. DOI: 10.1056/ NEJMoa2001017.

5. Huang C, Wang Y, Li X et al. Clinical features of patients infected with 2019novel coronavirus in Wuhan, China. www.thelancet.com January 24,
2020. http://doi.org/10.1016/s0140-6736(20)30183-5

6. WHO. Coronavirus disease (COVID-2019) Pandemic. (Accessed on March 2020): https:/www.who.int/ emergencies/diseases/novel-coronavirus-2019.

7. Guan W, Ni Z, Hu Y et al. Clinical characteristics of Coronavirus Disease 2019 in China. New Eng J Med 2020; DOI: 10.1056/NEJMoa2002032.

8. Lai MM, Cavanagh D. The molecular biology of coronaviruses. Adv Virus Res 1997; 48: 1-100. doi:10.1016/S0065-3527(08)602869. ISBN 9780120398485. PMID 9233431.

9. Brian DA, Baric RS. Coronavirus Genome Structure and Replication. In: Coronavoirus Replication and Reverse Genetics. Edit. Compans RW, Cooper M, Honjo $\mathrm{T}$ et al. Springer-Verlag Berlin Heidelberg, Germany 2005: 1-30. 
10. de Groot RJ, Baker SC, Baric $\mathrm{R}$ et al. Family Coronaviridae. In: King AM, Lefkowitz E, Adams MJ, Carstens EB, International Committee on Taxonomy of Viruses, International Union of Microbiological Societies. Virology Division (eds.). Ninth Report of the International Committee on Taxonomy of Viruses. Oxford: Elsevier 2011: 806-28. ISBN 978-0-12-384684-6.

11. Guo YR, Cao QD, Hong ZS et al. The origin, transmission and clinical therapies on coronavirus disease 2019 (COVID-19) outbreak - an update on the status. Military Med Res 2020; 7: 11. https://doi. org/10.1186/s40779-020-00240-0.

12. Li Q, Guan X, Wu P et al. Early transmission dynamics in Wuhan, China, of novel coronavirus infected pneumonia. New Eng J Med 2020 [PMID:31995857] doi: 10.1056/NEJM oa 2001316.

13. Lauor SA, Grantz KH, Bi Q et al. The incubation period of Coronavirus Disease 2019 (COVID-19) for publicly reported confirmed cases: estimation, application. Ann Int'l Med 2020. doi: 10.7326 M 20. 0504.

14. Paules CI, Marston HD, Fauci AS. Corona virus infections-more than just the common cold. J Amer Med Assoc (Viewpoint) 2020; 323: 707-8. DOI: http:// jamanetwork.com/on 02/11/2020.

15. Rodriguez-Morales AJ, Bonilla-Aldana DK, BalbinRamon GJ et al. History is repeating itself: probable zoonotic spillover as the cause of the 2019 novel coronavirus epidemic. Le Infeczioni in Medicina,n. (Editorial) 2020; 1: 3-5.

16. Chan JF-W, Yuan S, Kok K-H et al. A familial cluster of pneumonia associated with the 2019 novel coronavirus indicating person to person transmission; a stuhttps://doi.org/10.1016/S01406736(20)30154-9.

17. Wong CK,LamCWK,Wu AKL et al. Plasma inflammatory cytokines and chemokinesin severe acute respiratory syndrome. Clin Experimental Immunol 2004; 136: 95-103.

18. Mahallawi WH, Khabour OF, Zhang Q, Makhdoum $\mathrm{HM}$, Suliman BA. MERS-CoV infection in human is associated with a proinflammatory Th1 and Th 17 cytokine profile. Cytokine 2018; 104: 8-13.

19. Tisoncik JR, Korth MJ, Simmons CP, Farrar J, Martin TR, Katze MG. Into the eye of the cytokine storm. Microbiol Mol Biol Rev 2012; 76: 16-28.

20. Zhou F, Yu T, Du R et al. Clinical course and risk factors for mortality of adult inpatients with COVID-19 in Wuhan, China: a retrospective cohort study. The Lancet 2020; DOI: http://doi. org/10.1016/50140-6736(20)30566-3.

21. WHO. 2019-nCoV/Lboratory/2020.1. Laboratory testing of human suspected cases of novel coronavirus (nCoV) infection: Interim guidelines 10 January 2020. 1-6.

22. Liu J, Cao R, Xu M et al. Hydroxychloroquine, a less toxic derivative of chloroquine, is effective in inhibiting SRAS-CoV-2 infection in vitro. Cell Discovery 2020; 6: 16. http://doi.org/10.1038/ s41421-020-0156-0.

23. Mauthe M, Orhon I, Rocchi $\mathrm{C}$ et al. Chloroquine inhibits autophagic flux by decreasing autophagosome-lysosome fusion. Autophagy 2018; 14: 1435-55. 